DOI: $10.2478 /$ lpts-2020-0003

\title{
3-WAY LUNAR RADIO RANGING EXPERIMENT ON RT-32 RADIO TELESCOPES
}

\author{
D. Marshalovi*, J. Ping 2 , W. Li², M. Wang'2, J. Sun ${ }^{2}$, \\ Yu. Bondarenko ${ }^{1}$, M. Vasilyev ${ }^{1}$, E. Yagudina ${ }^{1}$ \\ ${ }^{1}$ Institute of Applied Astronomy, Russian Academy of Sciences, \\ 10 Nab. Kutuzova, 191187, St.Petersburg, RUSSIA \\ ${ }^{2}$ National Astronomical Observatories, Chinese Academy of Sciences, \\ 20A Datun Road, 100012, Beijing, CHINA \\ *e-mail:marshalov@iaaras.ru
}

Since 2017, the Institute of Applied Astronomy of the Russian Academy of Sciences in cooperation with the National Astronomical Observatories of the Chinese Academy of Sciences has been conducting observations of the Chang'E-3 lander carrier wave signal. The paper presents the features of observation scheduling and results of data processing. High-precision phase radar measurements have been obtained with an instrumental error of 1-2 $\mathrm{mm}$. The deviation of residuals in model calculations does not exceed $\pm 1 \mathrm{~cm}$. The estimates of CE-3 lander position have been obtained with an accuracy of 0.5 ", $7.4 \mathrm{~m}$ and $3.2 \mathrm{~m}$ in celenocentric cylindrical longitude, Px and Py coordinates, respectively.

Keywords: Chang'E-3, digital phase lock loop, lunar ephemeris, lunar radio ranging, phase measurement, radio telescope

\section{INTRODUCTION}

In December 2013, the Chinese spacecraft Chang'E-3 (CE-3) landed on the surface of the Moon [1]. The lander was equipped with the transceiver device (transponder) operating in the X-band. The transponder was designed to receive a $7.2 \mathrm{GHz}$ signal and its coherent reradiation at a frequency of $8.47 \mathrm{GHz}$.

Radio telescopes at Jiamusi and Kashi stations of the Chinese Deep Space Network with $66 \mathrm{~m}$ and $35 \mathrm{~m}$ antennas [2] regulary transmit the signal to CE-3. Reradiated signal from the transponder is recorded simultaneously by the $32 \mathrm{~m}$ radio telescopes (RT-32) at Svetloe, Zelenchukskaya and Badary observatories [3], as well as by the radio telescopes at the Seshan, Kunming and Urumqi observatories that are part of the National Astronomical Observatories of the Chinese Academy of Sciences 
(NAOC). Thus, the Lunar Radio Ranging (LRR) technique was implemented, which allowed estimating the lander position and the model parameters of the orbital and rotational motion of the Moon regardless of lunar laser ranging (LLR) observations [4]. Expected impact of the LRR observations on the lunar ephemeris accuracy was estimated using numerical simulation [5].

Compared with the LLR, LRR has several advantages such as independence of weather conditions and the phase of the Moon, reduced requirements for target tracking accuracy, simultaneous observation by several stations and a larger number of stations that can record a signal. Simultaneous reception of a transponder signal by two or more radio telescopes is called 3-way LRR, reducing the uncertainty in lander position, but increasing the number of estimated parameters. In the following sections, we present the description of the methods used and the results of LRR experiments.

\section{OBSERVATIONS AND DATA PROCESSING}

A software complex was developed for scheduling LRR observations. It determined joint observation windows and formed an ephemeris file for a specified configuration of the transmitting and receiving antenna systems and selected nearEarth object (asteroid, comet or spacecraft). Planetary ephemeris DE430 [6] and corrections to the Earth's rotation parameters (the pole coordinates, the precession, the nutation, and the universal time) were used in the software complex to calculate the ephemeris files for the radio telescope control system.

Observations were carried out automatically on RT-32 according to a schedule in X-band [7]. A signal from CE-3 transponder with a frequency of $8.47 \mathrm{GHz}$ was recorded, taking into account the Doppler shift. The radio telescope receiving system converted the signal from SHF to an intermediate frequency of $390 \mathrm{MHz}$. Then, the data acquisition system P1002M [8] converted the signal to video frequencies in the $2 \mathrm{MHz}$ bandwidth from intermediate frequencies. The data were recorded by the Mark5B registration system with two-bit sampling. Then, the recorded data were transmitted for processing by the optical fibre channels.

Processing of observation data was divided into two stages. At the first stage of processing, the integrated observable phase $\varphi$ of the recorded signal at a given time was calculated. Using the obtained phase $\varphi$, at the second stage, the selenocentric coordinates of the lander and phase ambiguities, corrections to time scales of the observatories, tropospheric and ionospheric delays were determined.

The digital phase-locked loop (DPLL) was used to calculate the integral phase $\varphi$ of the recorded signal [9]. The implemented algorithm is shown in Fig. 1. The input signal was multiplied by the current value of the digital signal generator with the model phase $\varphi_{n}$. Then the resulting complex signal was accumulated over an update interval. Residual phase $\tilde{\varphi}_{n}$ for the given $n$-th interval was calculated as the complex sum $U$ argument. Residual phase was passed to the loop filter to assist in the generation of model phase rate. The 3rd-order digital loop filter used residual phase values $\tilde{\varphi}_{n}$ to estimate phase rate $\dot{\varphi}_{n+1}$ for the $(n+1)$-th interval according to 


$$
\dot{\varphi}_{n+1} T=K_{1} \tilde{\varphi}_{n}+K_{2} \sum_{i=1}^{n} \tilde{\varphi}_{i}+K_{3} \sum_{i=1}^{n} \sum_{j=1}^{i} \tilde{\varphi}_{j}
$$

where $\dot{\varphi}_{n+1} T$ is phase change per update interval $T=0.01 \mathrm{sec}$ and loop coefficients $K_{1}=5.218 \mathrm{E}-2, K_{2}=1.210 \mathrm{E}-3, K_{3}=1.052 \mathrm{E}-5$ for loop noise bandwidth of $2 \mathrm{~Hz}$. Then these values were used to calculate the next model phase $\varphi_{n}$, while the observable phase $\varphi$ was obtained from $\varphi_{n}$ and phase residual $\tilde{\varphi}_{n}$ at a given time.

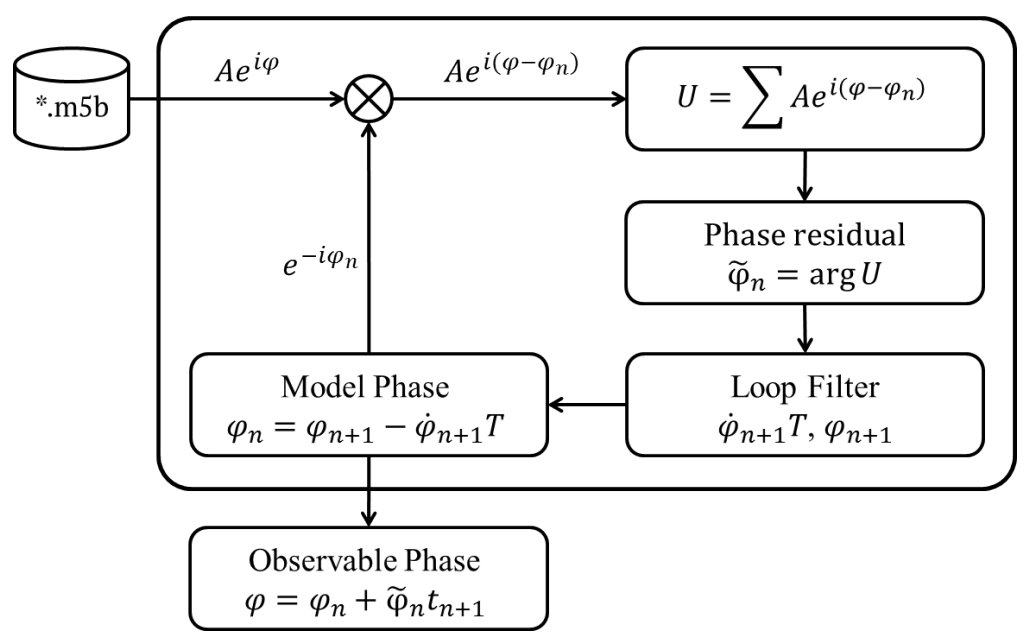

Fig. 1. Algorithm of the digital phase-locked loop for obtaining observable phase.

To compensate the influence of the atmosphere on the propagation of radio signals, we used tropospheric and ionospheric delays from IGS data. The tropospheric delay was calculated using Vienna mapping functions based on the weather data of each station. For this purpose, wet and hydrostatic delays at the zenith were determined. The zenith delay was projected onto the source-station line of sight using the mapping function [13]. The ionosphere was modelled by one thin layer at an altitude of $450 \mathrm{~km}$ above the Earth's surface. To calculate the ionospheric delay, the mapping function [12] was used.

Phase modelling used the following data and models:

- EPM-2014 [10] ephemeris to calculate geocentric position of the Moon and lunar rotation parameters;

- $\quad$ LRR and LLR observational models implemented in ERA system [11], which included all required IERS recommendations [12];

- for each radio telescope and observation interval, phase ambiguity, zenith wet delays and station clocks were adjusted.

As a result, the corrections to a priori values of the CE-3 lander coordinates were obtained. Parameters of the orbital and rotational motion of the Moon, radio telescope positions, as well as Earth orientation parameters were not estimated but fixed to their a priori values. 


\section{RESULTS}

During the period from December 2017 to June 2018, six CE-3 3-way LRR observation sessions were successfully conducted. We also had 2-way LRR data obtained in 2014. Table 1 presents the dates of observations, configurations of receiving-transmitting stations and instrumental accuracy obtained for each observation session expressed in standard deviations (RMS) of the integral phase in $\mathrm{mm}$.

Table 1

CE-3 Observations Obtained in 2014 and 2017/2018

\begin{tabular}{|l|c|c|}
\hline Date & Configuration & Phase RMS, mm \\
\hline $2014-11-13$ & Jiamusi-Jiamusi & - \\
\hline $2014-12-03$ & Jiamusi-Jiamusi & - \\
\hline $2014-12-04$ & Jiamusi-Jiamusi & - \\
\hline $2014-12-05$ & Jiamusi-Jiamusi & - \\
\hline $2014-12-06$ & Jiamusi-Jiamusi & - \\
\hline $2014-12-07$ & Jiamusi-Jiamusi & - \\
\hline $2014-12-08$ & Jiamusi-Jiamusi & 1.17 \\
\hline $2014-12-09$ & Jiamusi-Jiamusi & 1.28 \\
\hline $2014-12-10$ & Jiamusi-Jiamusi & 2.01 \\
\hline $2017-12-07$ & Kashi-Svetloe & 2.95 \\
\hline $2017-12-10$ & Kashi-Svetloe & 1.72 \\
\hline $2018-03-31$ & Jiamusi-Badary & 2.13 \\
\hline $2018-04-02$ & Jiamusi-Badary & - \\
\hline $2018-06-25$ & Kashi-Badary & - \\
\hline $2018-06-27$ & Kashi-Badary & \\
\hline
\end{tabular}

We obtained the selenocentric coordinates of the lander, tropospheric and ionospheric delays, and corrections to the time scales of the observatories. As a result, the deviation of phase residuals in model calculations did not exceed $\pm 10.0 \mathrm{~mm}$ (see Fig. 2). The estimates of CE-3 lander position were obtained to be $19.532^{\circ} \mathrm{W}$, $1245291.01 \mathrm{~m}$ and $1208076.4 \mathrm{~m}$, with rms deviation $0.5 ", 7.4 \mathrm{~m}$ and $3.2 \mathrm{~m}$ in selenocentric cylindrical longitude, $\mathrm{P}_{\mathrm{x}}$ and $\mathrm{P}_{\mathrm{y}}$ coordinates, respectively. Principal Axis (PA) coordinate system of EPM [10] ephemeris was used in this study.

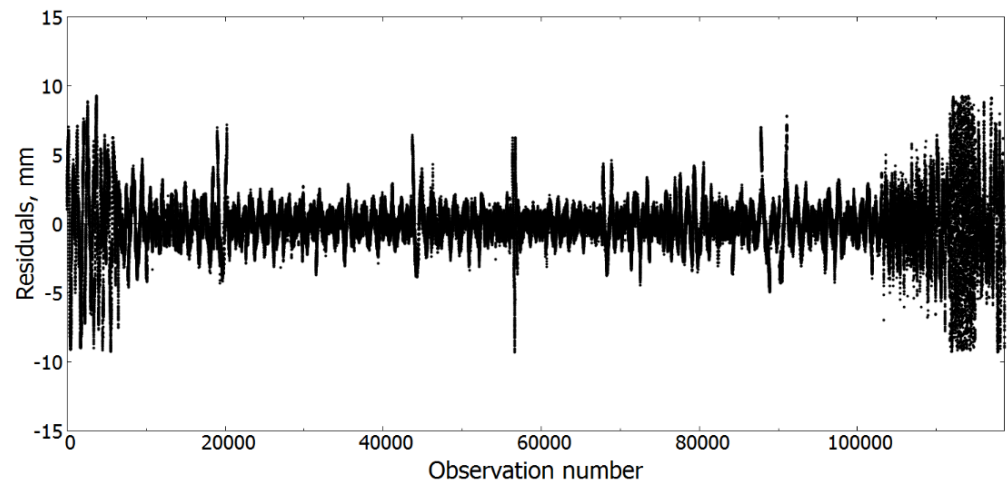

Fig. 2. Residuals of 2-way and 3-way LRR-observation. 


\section{CONCLUSIONS}

The analysis of residuals of LRR observations confirmed high accuracy of the performed measurements. The standard deviation of phase LRR observations was 1-3 mm. LRR observation residuals obtained from the Kashi-Badary configuration did not exceed $\pm 10.0 \mathrm{~mm}$.

Using 2-way LRR observations carried out in 2014, the selenocentric PA coordinates of CE-3 lander were determined, the values of which were: $\mathrm{X}=1173627.868 \mathrm{~m}, \mathrm{Y}=-416350.220 \mathrm{~m}$ and $\mathrm{Z}=1208076.399 \mathrm{~m}$. A comparison with the results obtained from 3-way observations during 2017-2018 showed a good match.

\section{ACKNOWLEDGEMENTS}

The work of D. Marshalov and Yu. Bondarenko in terms of conducting and processing the phase radar observations has been supported by the Russian Science Foundation under grant No. 16-12-00071 and performed at the Institute of Applied Astronomy of the Russian Academy of Sciences.

\section{REFERENCES}

1. Li, C., Liu, J., Ren, X., Zuo, W., Tan, X., Wen W., ... \& Uuyang, Z. (2015). The Chang'e 3 Mission Overview. Space Science Reviews, 190, (1-4), 85-101.

2. Xu, D., Dong, G., Wang, G., Li, H., \& Jiang, W. (2016). First Geodetic VLBI Sessions with the Chinese Deep Space Stations Jiamusi and Kashi. Advances in Space Research, $58,1638-1647$.

3. Ivanov, D.V., Uratsuka, M.-R., Ipatov, A.V., Marshalov, D.A., Shuygina, N.V., Vasilyev, M.V., ... \& Suvorkin, V.V. (2018). Russian-Cuban Colocation Station for Radio Astronomical Observation and Monitoring of Near-Earth Space. Astrophysical Bulletin, 73 (2), 257-266.

4. Ping, J., Meng, Q., Wang, M., Tang, G., Jian, N., Wang, Z., ... \& Cao, J. (2014). First 3-Way Lunar Radio Phase Ranging and Doppler Experiment in Chang'E-3 Lander Mission. In European Planetary Science Congress 2014, EPSC Abstracts, 9, EPSC2014226-1.

5. Vasilyev, M.V., Shuygina, N.V., \& Yagudina, E.I. (2017). Expected impact of the Lunar Lander VLBI Observations on the Lunar Ephemeris Accuracy. IAA RAS Transections, 40, $16-21$.

6. Folkner, W.M., Williams, J.G., Boggs, D.H., Park, R.S., \& Kuchynka, P. (2014). The Planetary and Lunar Ephemerides DE430 and DE431. IPN Progress Report 42-196.

7. Marshalov, D.A., Bondarenko, Yu.S., Medvedev, Yu.D., Vavilov, D.E., Zotov, M.B., \& Mikhailov, A.G. (2018). A Complex for Carrying Out Radar Observations of Near-Earth Objects. Instruments and Experimental Techniques, 61 (4) , 577-582.

8. Grenkov, S.A., Nosov, E.V., Fedotov, L.V., \& Kol'tsov, N.E. (2010). A Digital Radio Interferometric Data Acquisition System. Instruments and Experimental Techniques, 53 (5), 675-681.

9. Thomas, J.B. (1989). An Analysis of Digital Phase-Locked Loops. JPL Publication 89-2. 
10. Vasilyev, M.V., \& Yagudina, E.I. (2014). Russian Lunar Ephemeris EPM-ERA 2012. Solar System Research, 48 (2), 158-165.

11. Krasinsky, G.A., \& Vasilyev, M.V. (1997). ERA: Knowledge Base for Ephemeris and Dynamical Astronomy. IAU Colloquium, 165, 239-244.

12. IERS Conventions. (2010). IERS Technical Note No.36.

13. Boehm, J., Werl, D., \& Schuh, H. (2006). Troposphere Mapping Functions for GPS and Very Long Baseline Interferometry from European Centre for Medium-Range Weather Forecasts Operational Analysis Data. J. Geophys. Res., 111, B02406.

\title{
TRĪSVIRZIENU MĒNESS RADIO PĀRRAIDES EKSPERIMENTS UZ RT-32 RADIOTELESKOPIEM
}

\author{
D. Maršalovs, Dž. Pings, V. Li, M. Vangs, Dž. Sans, \\ J. Bondarenko, M. Vasiljevs, E. Jagudina
}

Kopsavi $1 \mathrm{kums}$

Kopš 2017. gada Krievijas Zinātņu akadēmijas Lietišķās astronomijas institūts sadarbībā ar Ķīnas Zinātņu akadēmijas Nacionālajām astronomiskajām observatorijām veic Chang'E-3 piezemēšanās nesēja viḷna signāla novērojumus. Darbā aprakstītas novērojumu plānošanas iezīmes un datu apstrādes rezultāti. Augstas precizitātes fāzes radara mērījumi tika iegūti ar instrumentālo kḷūdu 1-2 $\mathrm{mm}$. Atlikumu novirze modeḷa aprēḳinos nepārsniedz $\pm 1 \mathrm{~cm}$. CE-3 piezemēšanās ierīces stāvokḷa aprēķini tika iegūti ar precizitāti 0,5“, 7,4 m un 3,2 m attiecīgi celenocentriskā cilindriskā garumā, Px un Py koordinātēs.

Atslēgas vārdi: Chang'E-3, ciparu fāzes bloḳēšanas cilpa, Mēness efemers, Mēness radio diapazons, fāzes mērī̌sana, radioteleskops 